
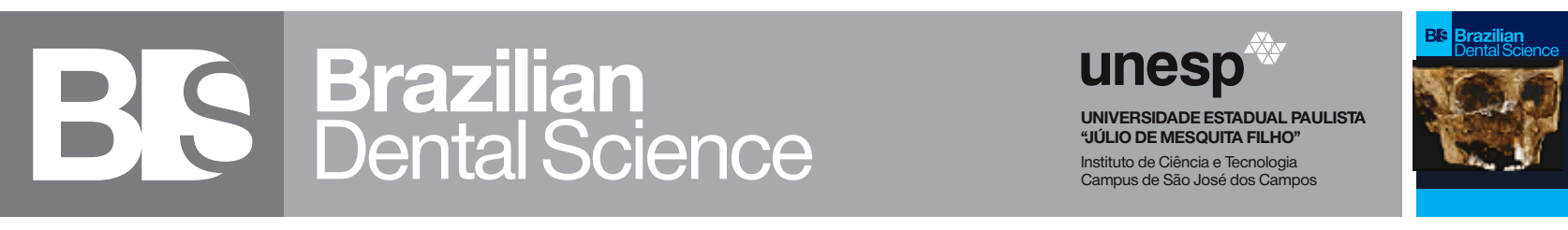

\title{
Effect of decontamination methods on shear bond strength of resin cement to translucent monolithic zirconia
}

Efeito de métodos de descontaminação na resistência ao cisalhamento entre cimento resinoso e zircônia monolítica translúcida

\author{
Mazen A. ATTIA ${ }^{1}$, Kamal EBEID ${ }^{2,3}$ \\ 1 - Beni-Suef University, Faculty of Dentistry, Fixed Prosthodontics Department, Beni-Suef, Egypt. \\ 2 - Ain Shams University, Faculty of Dentistry, Fixed Prosthodontics Department, Cairo, Egypt. \\ 3 - College of Dentistry, Gulf Medical University, Ajman, UAE.
}

\section{ABSTRACT}

Objective: The aim of this study was to evaluate the effect of decontamination methods on shear bond strength of resin cement to translucent monolithic zirconia. Material and Methods: Eighty 4-mol yttriastabilized tetragonal zirconia polycrystal specimens were fabricated. All specimens were subjected to saliva contamination and divided into four groups ( $\mathrm{n}$ $=20$ ) according to the decontamination methods: $70 \%$ isopropanol (AL); zirclean (ZC); $5.25 \%$ sodium hypochlorite (NaOCL); and no cleaning (NC). All specimens were bonded by using self-adhesive resin cement. Half of the specimens in each group ( $\mathrm{n}=$ 10) were subjected to aging. All specimens were subjected to shear bond strength test in a universal testing machine. Failure modes were evaluated by using a scanning electron microscope (SEM). The data obtained were statistically analyzed by using one-way ANOVA followed by the HSD Tukey test ( $\mathrm{p}$ $<0.05)$. Results: ANOVA test revealed a significant difference among the different decontamination methods $(\mathrm{p}<0.05)$. No significant differences were found among NaOCL, ZC, and AL groups as revealed by the HSD Tukey test $(\mathrm{p}>0.05)$. The effect of aging was significantly different in all groups $(\mathrm{p}<0.05)$; whereas, no significant difference was found in group ZC ( $p>0.05)$. The (SEM) analysis showed mixed failures in all groups, except in group NC where only adhesive failure was observed. Conclusion: Saliva contamination during clinical evaluation significantly decreases the shear bond strength between selfadhesive resin cement and translucent monolithic zirconia. The cleaning methods have an impact on improving the bond strength between resin cement and translucent monolithic zirconia.

\section{KEYWORDS}

Monolithic zirconia; Resin cement; Shear bond strength test; Translucent zirconia; Zirclean.

\section{RESUMO}

Objetivo: O objetivo deste estudo foi avaliar o efeito dos métodos de descontaminação na resistência ao cisalhamento entre cimento resinoso e zircônia monolítica translúcida. Material e métodos: Foram fabricados oitenta espécimes policristalinos de zircônia tetragonal estabilizada com ítria a 4 mol. Todas as amostras foram submetidas à contaminação salivar e divididas em quatro grupos (n $=20$ ) de acordo com os métodos de descontaminação: isopropanol a 70\% (AL); zircleano (ZC); Hipoclorito de sódio a 5,25\% (NaOCL); e sem limpeza (NC). Todas as amostras foram cimentadas utilizando um cimento resinoso autoadesivo. Metade das amostras de cada grupo $(\mathrm{n}=10)$ foram submetidas ao envelhecimento. Todas as amostras foram submetidas ao teste de resistência ao cisalhamento em uma máquina de teste universal. Os módulos de falha foram avaliados usando um microscópio eletrônico de varredura (MEV). Os dados obtidos foram analisados estatisticamente utilizando ANOVA de uma via, seguida pelo teste de HSD Tukey $(\mathrm{p}<0,05)$. Resultados: O teste ANOVA revelou diferença significativa entre os diferentes métodos de descontaminação $(p<0,05)$. Não foram encontradas diferenças significativas entre os grupos $\mathrm{NaOCl}, \mathrm{ZC}$ e AL, conforme revelado pelo teste HSD Tukey $(p>0,05)$. O efeito do envelhecimento foi significativamente diferente em todos os grupos $(p<0,05)$; enquanto nenhuma diferença significativa foi encontrada no grupo ZC ( $p>0,05)$. A análise (SEM) mostrou falhas mistas em todos os grupos, exceto no grupo NC, onde apenas foi observada falha adesiva. Conclusão: A contaminação por saliva durante a avaliação clínica diminui significativamente a resistência ao cisalhamento entre o cimento resinoso autoadesivo e a zircônia monolítica translúcida. Os métodos de limpeza têm um impacto na melhoria da resistência da união entre o cimento resinoso e a zircônia monolítica translúcida.

\section{PALAVRAS-CHAVE}

Zircônia monolítica; Cimento resinoso; Teste de resistência ao cisalhamento; Zircônia translúcida; Zircônia. 


\section{INTRODUCTION}

$\mathrm{T}$ raditional 3-mol yttria-stabilized tetragonal zirconia polycrystal (3Y-TZP) restorations have been widely used in prosthetic dentistry due to their acceptable optical properties, superior mechanical properties, excellent biocompatibility, and less wear to the opposing dentition $[1,2]$. In addition, more conservative tooth preparation can be obtained particularly in patients with limited interocclusal space and parafunctional habits; however, the lack of translucency is considered their main drawback [3].

To improve translucency, super translucent 4-mol yttria-stabilized tetragonal zirconia polycrystal (4Y-TZP) materials containing tetragonal and cubic grains have been recently introduced [4]. Zirconia manufacturers increased the yttria content from 3 to $5 \mathrm{~mol} \%$ enabling low phase transformation toughening where the tetragonal phase can be retained at room temperature; however, accomplishing high translucency resulted in diminished fracture toughness of 2.5 to $3.5 \mathrm{MPa} \backslash \mathrm{m}^{1 / 2}$ and flexural strength of approximately 700 to $800 \mathrm{MPa}$ [57]. Another noticeable reason for introducing these restorations is the high incidence of porcelain chippings (6\% to $25 \%$ after 3 years) in bilayered zirconia ceramic restorations, which is significantly higher than the rates reported for metal-ceramic restorations [8-10].

The new generation of (4-YTZP) restorations is milled from pre-shaded super translucent multilayered (STML) blanks by using computer-aided design and computeraided manufacturing (CAD-CAM) technology [1]. The restoration color is homogeneous and can be easily polished by using special polishing materials [11]. Monolithic zirconia restorations can be luted by using conventional cement [12] or bonded by using adhesive resin cement which are considered the cement of choice for many clinical applications [13,14].

However, zirconia-resin bond strength is influenced by many factors, such as the ceramic wettability by adhesive resin cement, surface treatment of zirconia, the chemical composition of adhesive resins and probable contamination during bonding [15-19]. Several methods have been proposed to enhance zirconia-resin bond strength, such as acid etching, tribochemical silica coating, airborne-particle abrasion by using $50 \mu \mathrm{m}$ aluminum oxide particles $\left(\mathrm{Al}_{2} \mathrm{O}_{3}\right)$, laser irradiation, and selective infiltration etching [20-24]. In addition; the application of 10-methacryloyloxydecyldihydrogenphosphate (10-MDP) or ester phosphoric methacrylate monomers after airborne-particle abrasion has been recommended to enhance zirconia-resin bond strength $[25,26]$. The enhanced bonding resulted from a chemical reaction that occurs between the phosphate ester monomer of the containing cement and the hydroxyl groups of the zirconia ceramic $[27,28]$.

The zirconia treated surface can easily become contaminated with saliva during the clinical evaluation [29]. The deposition of a thin film of organic phosphates on the zirconia surface after a few $s$ of saliva contamination is difficult to be removed with water resulting in reduced zirconia-resin bond strength [30]. The decontamination of the intaglio surface of zirconia restorations has been proposed in different studies, such as water rinse, $37 \%$ phosphoric acid, 70\% isopropanol, hydrogen peroxide, and sodium hypochlorite (NaOCL) [3137]. In addition, a new cleaning agent has been developed to absorb the phosphate contaminants from the intaglio surface of zirconia restorations to improve zirconia- resin bond strength $[38,39]$.

Saliva contamination during the clinical evaluation of (4-YTZP) restorations can reduce their bond strength to resin cement. Limited data are available on the bonding performance of zirconia to resin cement after saliva decontamination; thus, the shear bond test is employed to evaluate the adhesive interfaces $[40,41]$. The aim of this study was to evaluate the effect of decontamination methods on shear bond strength of resin cement to translucent monolithic zirconia. The null hypothesis was that different decontamination methods would not affect the bond strength between adhesive resin cement and translucent monolithic zirconia. 


\section{MATERIAL AND METHODS}

A power analysis was performed to estimate the sample size to apply a statistical test of the research null hypothesis that there would be no difference in the effect of different decontamination methods on the shear bond strength of resin cement to translucent monolithic zirconia. Based on Tunc et al [34], a sample size of 24 specimens had a $95 \%$ power to detect a difference between means as received from the study with a significant level $(\alpha=.05)$, and it was increased to 80 specimens $(n=20)$ per group to achieve more reliable results. Sample size calculation was performed using a statistical software program ( $G^{*}$ Power v3.1.9.22).

\section{Specimens preparation}

The materials used in the present study are listed in Table I. A total of 80 specimens $(14 \times 14$ $\times 2.5 \mathrm{~mm}$ ) were milled from a partially sintered (4Y-TZP) blank by using a precision saw machine (Isomet 4000; Buehler, Lake Bluff, IL, USA) under constant irrigation. The specimens were sintered in a special sintering furnace (5 motions furnace; Bredent, Senden, Germany) at $1550{ }^{\circ} \mathrm{C}$ according to the manufacturer instructions. Anticipating 20\% volumetric shrinkage, the final dimension of the specimens was approximately $(12 \times 12 \times 2 \mathrm{~mm})$. All specimens were sequentially wet polished with 600-grit rotating silicon carbide paper (Buehler, Lake Bluff, IL, USA) and air-abraded by using 50 $\mu \mathrm{m}$ AL2O3 particles (Protechno, Girona, Spain) at $0.25 \mathrm{MPa}$ pressure in an airborne-particle abrasion unit (ESB 2; Eurocem Srl, Milanese, Italy) for $15 \mathrm{~s}$ at a distance of $10 \mathrm{~mm}$.

Table I - Materials used in this study.

\begin{tabular}{|c|c|c|c|}
\hline Material & Manufacturer & Lot No. & Composition \\
\hline $\begin{array}{l}\text { Katana } \\
\text { Zirconia } \\
\text { STML }\end{array}$ & $\begin{array}{l}\text { Kuraray Noritake } \\
\text { Dental Inc, Aichi, } \\
\text { Japan }\end{array}$ & DYBIR & $\begin{array}{c}\text { 4Y-TZP; }\left(\mathrm{ZrO}_{2}+\mathrm{HfO}_{2}+\mathrm{Y}_{2} \mathrm{O}_{3}\right) \\
>99 \% \text {, yttrium oxide } \\
\left(\mathrm{Y}_{2} \mathrm{O}_{3}\right)>4 \% \text {, hafnium oxide } \\
\left(\mathrm{HfO}_{2}\right) \leq 5 \% \text {, other oxides } \\
\leq 1 \%\end{array}$ \\
\hline Zirclean & $\begin{array}{l}\text { Bisco, Schaum- } \\
\text { burg, IL, USA }\end{array}$ & 1800007913 & $\begin{array}{l}\text { Zirconium oxide, water, } \\
\text { polyethylene glycol, } \\
\text { potassium hydroxide, } \\
\text { pigments, additives }\end{array}$ \\
\hline $\begin{array}{c}\text { RelyX } \\
\text { Unicem }\end{array}$ & $\begin{array}{l}\text { 3M ESPE, Seefeld, } \\
\text { Germany }\end{array}$ & 4348049 & $\begin{array}{l}\text { Powder: } \\
\text { glass powder, silica, cal- } \\
\text { cium hydroxide, initiator } \\
\text { Liquid: methacrylated } \\
\text { phosphoric acid ester, } \\
\text { dimethacrylate, initiator }\end{array}$ \\
\hline
\end{tabular}

\section{Surface decontamination methods}

The specimens were steam cleaned (EGV 18; Eurocem Srl, Milanese, Italy), air-dried, then contaminated with saliva. Saliva was obtained from one healthy male donor who had refrained from eating or drinking for $2 \mathrm{~h}$ before the collection process. The saliva was left undisturbed for $10 \mathrm{~min}$ and then rinsed with water for $15 \mathrm{~s}$ and air-dried for $15 \mathrm{~s}$ at a $10 \mathrm{~mm}$ distance. This procedure was performed following the ethical regulations of Faculty of Dentistry of Beni-Suef university (approval\# FDBSUREC/13032019/ FA).

Samples were assigned into 4 groups $(n=$ 20) according to the decontamination methods: Group AL: saliva contamination and immersion in 70\% isopropanol for $2 \mathrm{~min}$; Group ZC: saliva contamination and application of cleaning gel (Zirclean) by using a microbrush for $20 \mathrm{~s}$; Group NaOCL: saliva contamination and immersion in $5.25 \%$ percent sodium hypochlorite for 2 min; and Group NC: saliva contamination only. Subsequently, all specimens were rinsed with distilled water for $15 \mathrm{~s}$ and air-dried for $10 \mathrm{~s}$.

\section{Bonding procedures}

For standardization of the bonding surface area, tygon tubes ( $2 \mathrm{~mm}$ diameter, $2 \mathrm{~mm}$ height) were placed in the center of (4Y-TZP) specimens. The self-adhesive resin cement was mixed and pressed through the tubes against the (4Y-TZP) surfaces and light-cured from all directions for 40 $\mathrm{s}$ at $1250 \mathrm{~mW} \backslash \mathrm{cm} 2$ (Mini LED; Satelec Acteon Group, Mérignac Cedex, France). The tubes were carefully detached, and the resin cement cylinders were light-cured for an extra $40 \mathrm{~s}$. All specimens were stored in distilled water for $24 \mathrm{~h}$ at $37{ }^{\circ} \mathrm{C}$. Half of the specimens in each group $(n=10)$ were subjected to aging in distilled water between $5{ }^{\circ} \mathrm{C}$ and $55{ }^{\circ} \mathrm{C}$ for 5000 cycles (Thermocycler-1100; SD Mechatronik, Feldkirchen-W., Germany) before testing $[42,43]$. The dwell time was $20 \mathrm{~s}$ and the transfer time was $2 \mathrm{~s}$.

\section{Shear bond strength test}

The shear bond strength test was performed in a universal testing machine (Instron 3345; Instron Corp., Norwood, MA, USA) at a crosshead speed of $1.0 \mathrm{~mm} \backslash \mathrm{min}$ and a load cell of $5 \mathrm{KN}$ until failure occurred (Figure. 1). The data 
were recorded using computer software (Bluehill Lite; Instron Corp., Norwood, MA, USA) and the values were reported in MPa.

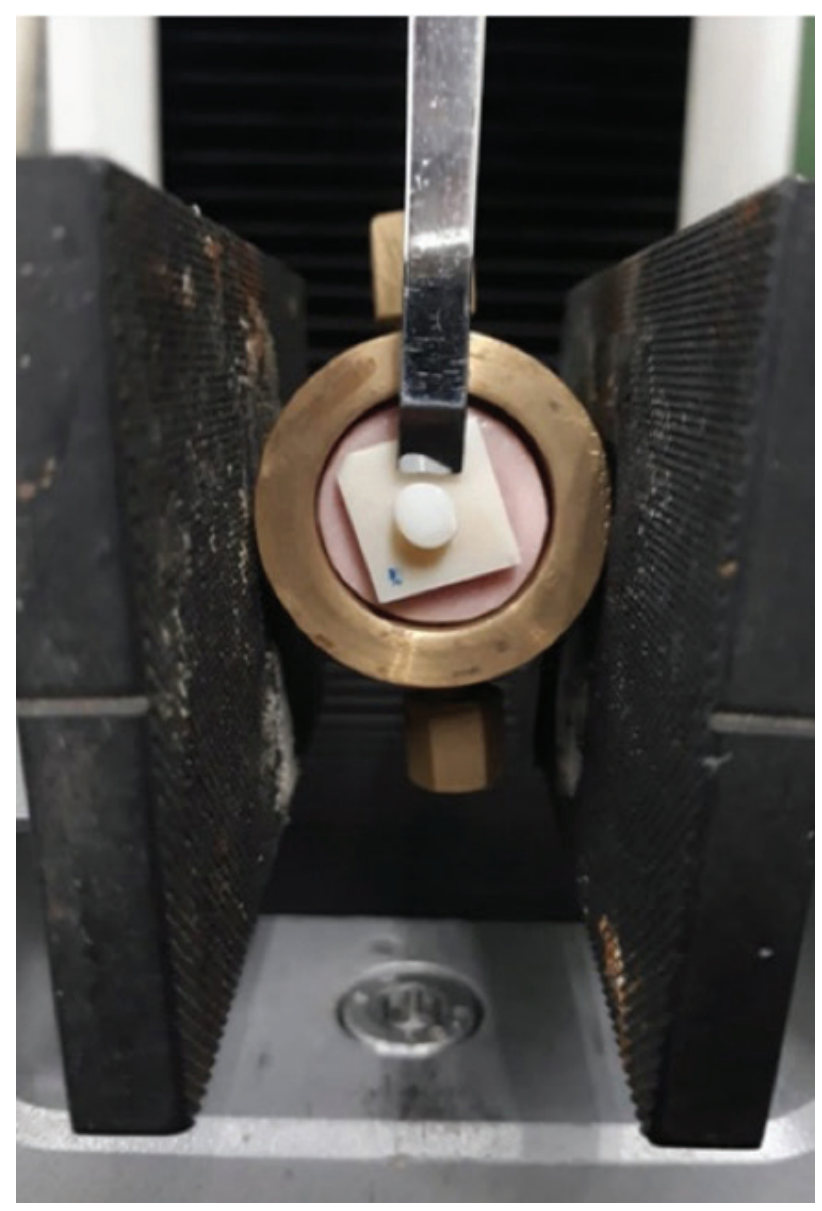

Figure 1- Specimen placed in universal testing machine for the shear strength test.

\section{SEM analysis}

Representative debonded specimen from each group was examined under a scanning electron microscope (Quanta 250 FEG; FEI, Netherlands) with an accelerating voltage of 30 $\mathrm{kV}$ at a magnification of $2500 \times$ to define the failure mode which was classified as adhesive failure including complete debonding between the resin cement and the (4Y-TZP) surface, cohesive failure within the resin cement, and mixed failure including retained cement on the (4Y-TZP) surface.

\section{Statistical analysis}

Numerical data were explored for normality by checking the distribution of data and using the Kolmogorov-Smirnov and ShapiroWilk tests. Data showed normal (parametric) distribution were presented as mean, standard deviation (SD). One-way ANOVA followed by HSD Tukey tests were used to study the effect of the decontamination methods ( $\mathrm{p}<0.05)$. T-test was used to study the effect of aging. Statistical analysis was performed by using a statistical software program (IBM SPSS Statistics v.20; SPSS Inc., Chicago, IL, USA).

\section{RESULTS}

The means and standard deviations of the shear bond strength values in MPa for all nonaged and aged groups are presented in Table II. One-way ANOVA test revealed that different decontamination methods had a statistically significant effect on the shear bond strength between (4Y-TZP) and the resin cement ( $\mathrm{p}$ $<$ 0.05); however, no statistically significant difference was found among NaOCL, ZC, and $\mathrm{AL}$ groups as revealed by the HSD Tukey test (p $>0.05$ ). Within each of the decontamination methods, the mean shear bond strength values decreased for all aged groups. The effect of aging was significantly different in group NaOCL ( $\mathrm{p}=$ $0.012)$, group $A L(p=0.004)$, and group $N C(p$ $=0.006$ ); however, no significant difference was observed in group ZC ( $\mathrm{p}=0.402)$.

Representative SEM images with 2500× magnification of debonded specimens after shear bond strength test demonstrated residual resin cement-retained on the (4Y-TZP) surfaces in non-aged and aged $\mathrm{AL}, \mathrm{ZC}$, and NaOCL groups. This observation indicated mixed failures with reasonable bond strength values; however, no residual resin cement remained on the (4Y-TZP) surface in group NC indicating adhesive failures between the resin cement and the (4Y-TZP) surface with reduced bond strength values (Figure. 2). 

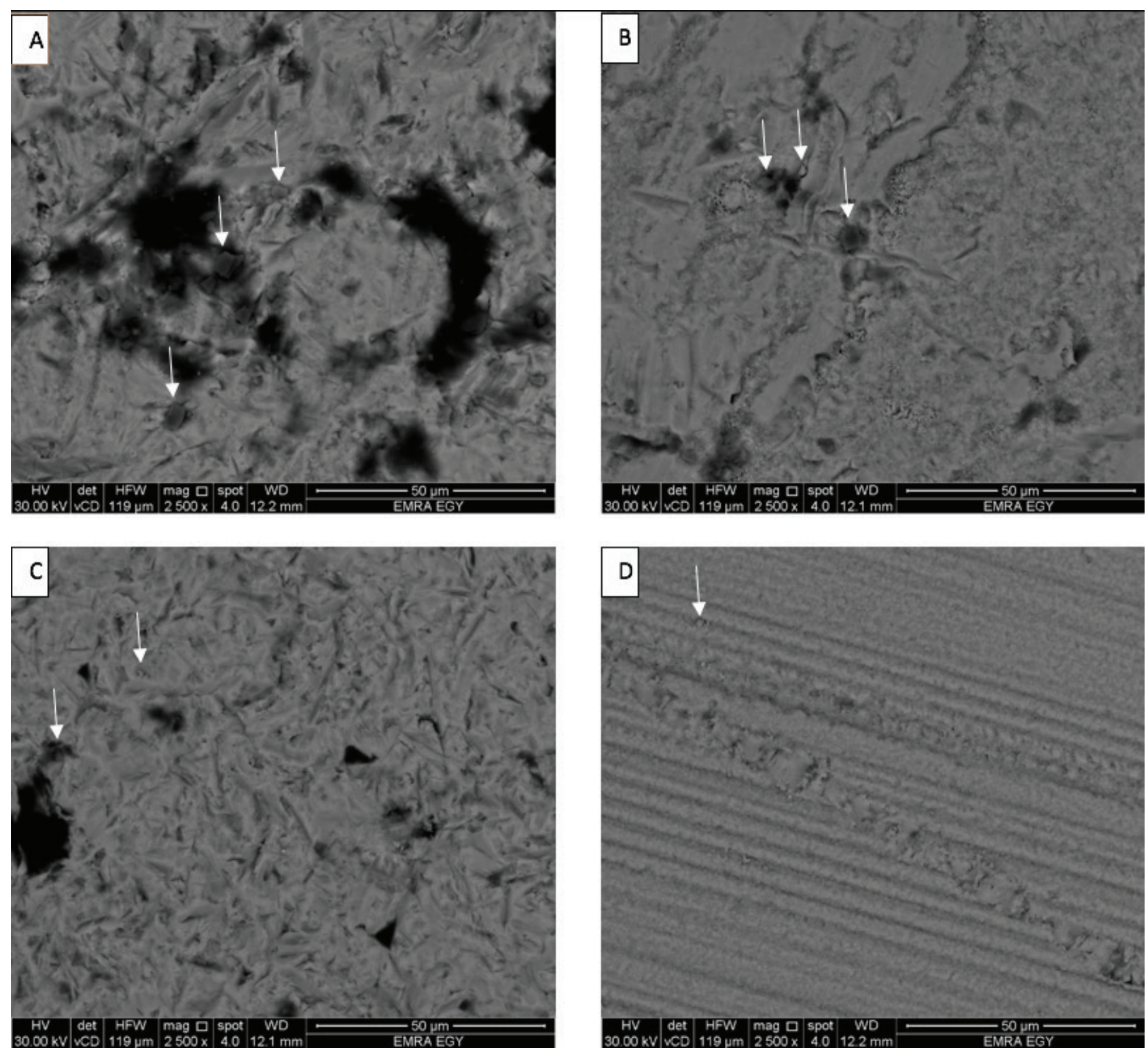

Figure 2 - Representative SEM image of debonded specimen from group ZC showing mixed failure with remnants of resin cement on the zirconia substrate. Original magnification 2500x (A); Representative SEM image of debonded specimen from group NaOCL showing mixed failure with small traces of resin cement on the zirconia substrate. Original magnification 2500× (B); Representative SEM image of debonded specimen from group AL showing mixed failure with small traces of resin cement on the zirconia substrate. Original magnification 2500× (C); Representative SEM image of debonded specimen from group NC showing adhesive failure with almost no remnants of resin cement on the zirconia substrate. Original magnification $2500 \times$ (D). 
Table II - Descriptive statistics of shear bond strength values (MPa), comparison between decontamination methods (ANOVA test) and the effect of aging (t-test)

\begin{tabular}{|c|c|c|c|c|c|c|c|}
\hline & & $\begin{array}{l}\text { Group } \\
\text { (ZC) }\end{array}$ & $\begin{array}{l}\text { Group } \\
\text { (NaOCL) }\end{array}$ & $\begin{array}{l}\text { Group } \\
\text { (Al) }\end{array}$ & $\begin{array}{l}\text { Group } \\
\text { (NC) }\end{array}$ & $\mathbf{F}$ & p \\
\hline \multirow{2}{*}{$\begin{array}{l}\text { Without } \\
\text { Aging }\end{array}$} & Mean & $21.62^{\mathrm{a}}$ & $20.02^{\mathrm{a}}$ & $19.12^{\mathrm{a}}$ & $8.85^{b}$ & \multirow{2}{*}{14.11} & \multirow{2}{*}{$0.000^{\star}$} \\
\hline & SD & 5.91 & 1.99 & 6.97 & 2.78 & & \\
\hline \multirow{2}{*}{$\begin{array}{l}\text { After } \\
\text { Aging }\end{array}$} & Mean & $16.99^{A}$ & $15.75^{\mathrm{A}}$ & $14.75^{A}$ & $5.38^{B}$ & \multirow{2}{*}{23.72} & \multirow{2}{*}{$0.000^{*}$} \\
\hline & SD & 3.44 & 2.94 & 4.72 & 2.15 & & \\
\hline \multirow{2}{*}{$\begin{array}{c}\text { Effect of } \\
\text { Aging }\end{array}$} & $t$ & 0.87 & 2.81 & 3.28 & 3.12 & & \\
\hline & $p$ & $0.402^{\mathrm{ns}}$ & 0.012 & $0.004^{*}$ & $0.006^{\star}$ & & \\
\hline
\end{tabular}

Significance level $p<0.05$; *significant, $n s=$ non-significant; Tukey's post hoc test: within the same comparison of different decontamination methods, means sharing the same superscript letter are not significantly different.

\section{DISCUSSION}

The null hypothesis that different decontamination methods would not affect the bond strength between adhesive resin cement and translucent monolithic zirconia was rejected. The results showed that different decontamination methods had a significant effect on zirconia-resin bond strength after saliva contamination.

The success of zirconia restorations depends on micro-mechanical retention and chemical adhesion of the resin cement to the zirconia surface, which necessitates efficient decontamination to ensure surface activation [18]. It has been reported that contamination with blood or saliva after clinical evaluation of zirconia restorations resulted in lower bond strength between resin cement and zirconia [29$31]$.

In the present study, $70 \%$ alcohol was used as a decontamination agent and the results showed lower shear bond strength values than those of groups ZC and NaOCL; however, this difference was not significant. The obtained results were consistent with those of Yang et al [29] and Quaas et al [35] who found that alcohol cleaning was not effective in removing the phosphate contaminants.

In addition, an extraoral cleaning gel (Zirclean) was used to decontaminate the translucent monolithic (4-YTZP) surface; however, information is lacking about the effect of this agent. Zirclean is an alkaline suspension of zirconium oxide particles, water, potassium hydroxide, and other additives. The high concentration and larger size of zirconium oxide particles act as a sponge that adsorbs the saliva phosphate contaminants rather than adherence to the zirconia surface, leaving behind a clean zirconia surface; therefore, enhancing zirconiaresin bond strength [32]. The results obtained in this study were consistent with those of Kim et al [40] who found that a reliable shear bond strength value could be obtained after Ivoclean application when compared to uncontaminated zirconia. In contrast, contradictory results have been reported by Aladag et al [38] and Ishii et al [39] who compared the effect of various surface decontamination methods, including Ivoclean cleaning paste on zirconia-resin bond strength and concluded no significant differences in the bond strength values.

Moreover, 5.25\% sodium hypochlorite was used in this study as a decontamination agent because of its capability to remove the salivary phosphates from the (4-YTZP) surface. The obtained bond strength values were found to be acceptable and consistent with those previously reported [36]. In contrast, it has been reported that excess sodium hypochlorite results in oxygen generation affecting the resin polymerization [37].

The shear bond strength values for nonaged and aged groups, showed statistically significant differences; however, these values 
exceed the minimum clinically acceptable bond strength value which is approximately 13 $\mathrm{MPa}[23,24]$. These results emphasize that the decontamination methods used in this study were effective to achieve reliable zirconia-resin bond strength $[31,40]$.

To maximize the clinical relevance of the present study; all (4-YTZP) specimens were air-abraded with $50 \mu \mathrm{m} \mathrm{Al} 2 \mathrm{O} 3$ to simulate the final restoration as delivered from the dental laboratory [17]. In addition, all specimens were subjected to saliva contamination to mimic the clinical evaluation of the restoration before the final cementation followed by application of the decontamination methods, and this has been confirmed by previous in vitro studies [30-32].

Based on previous studies [12,14,22], resin cement containing ester phosphoric methacrylate monomer was used in this study to enhance the zirconia-resin bond strength. It has been reported that the ester phosphoric methacrylate monomer present in the Relyx unicem was more efficient than MDP monomer for efficient zirconia bonding [26].

To evaluate the adhesive interfaces several tests have been used, such as the microshear, shear, microtensile, and tensile tests [41]. Although the microshear bond strength tests have been used in different studies [43-45], filling a tygon tube with the resin cement is very difficult resulting in many failures during specimen preparation, such as bubble inclusion and interfacial gap defect [44]. In addition, the pressure applied on the scalpel blade by the operator to remove the tygon tubes may be transferred to the resin cement cylinder. This resulted in the introduction of flaws, stress concentrations at the adhesive interface, and crack formation along the specimen. It was assumed that microshear specimens may fail prematurely due to the propagation of these cracks [45]. Therefore, the shear bond strength test was used in this study to evaluate the zirconia-resin bond strength after saliva contamination because of its simplicity, possibility of standardization, and simulating the clinical situation.
According to the International Organization for Standardization (ISO), all specimens in this study were subjected to aging protocol including 5000 cycles (equivalent to 6 months aging) in water between $5{ }^{\circ} \mathrm{C}$ and $55^{\circ} \mathrm{C}$ to simulate artificial aging in the wet oral cavity environment $[46,47]$. Based on the results of this study, a significant decrease in shear bond strength values was recorded in all groups subjected to aging, except in group ZC whereas no significant difference was found. This could be attributed to the successful removal of salivary contaminates by the decontamination gel; thus, improving the zirconia-resin bond strength.

The failure modes were evaluated using SEM and supported the bond strength results. The main failure mode of group NC was an adhesive failure in non-aged and aged specimens, showing that the durability of zirconia-resin bond strength was not satisfactory.

These findings were consistent with the results obtained by the authors in previous studies who reported lowest bond strength values when no cleaning was performed after contamination $[17,35]$. On the other hand, the failure mode in all non-aged and aged groups, was found to be a mixed failure indicating a reliable zirconia-resin bond strength; nevertheless, large remnants of resin cement were observed in group $\mathrm{ZC}$ indicating that it was the most efficient decontamination method. A possible explanation for the incidence of the adhesive and mixed failures could be attributed to the adhesive interface between the resin cement and the zirconia surface which was decontaminated with different decontamination methods.

limitations of this study included that the specimens were stored in water for $24 \mathrm{~h}$ which is not enough for water absorption by resin cements; thus, the present study provides information about the initial zirconia-resin bond strength. In addition, this study evaluated only the bond strength of zirconia to resin cement. Further studies to evaluate the resin cement shear bond strength to tooth structure including long-term water storage are required. 


\section{CONCLUSION}

Within the limitations of this study, the following conclusions were drawn:

1. Saliva contamination during clinical evaluation significantly decreases the shear bond strength between adhesive resin cement and translucent monolithic zirconia.

2. The decontamination methods improved the bond strength between adhesive resin cement and translucent monolithic zirconia, though not statistically significant.

3. Aging adversely affected the shear bond strength between adhesive resin cement and translucent monolithic zirconia.

4. Owing to their acceptable bond strength, translucent monolithic zirconia appears to be a promising monolithic restoration.

\section{REFERENCES}

1. Miyazaki T,Nakamura T,Matsumura H,Ban S, Kobayashi Current status of zirconia restoration.J Prosthodont Res.2013 0ct;57(4):236-61.doi:10.1016/j. jpor.2013.09.001.

2. Stober T,Bermejo JL, Rammelsberg P,Schmitter M. Enamel wear caused by monolithic zirconia crowns after 6 months of clinical use.J Oral Rehabil.2014 Apr;41(4):314-22.doi: 10.1111/joor.12139.

3. Sulaiman TA, Abdulmajeed AA, Donovan TE, Ritter AV, Vallittu PK, Närhi TO, Lassila LV. Optical properties and light irradiance of monolithic zirconia at variable thicknesses. Dent Mater.2015 0ct;31(10):1180-7.doi:10.1016/j. dental.2015.06.016

4. Ghodsi S, JafarianZ. A review on translucentzirconia.EurJ Prosthodont Restor Dent2018 May 30;26(2):62-74.doi:10.1922/EJPRD 01759Ghodsi13.

5. Mao L, Kaizer MR, Zhao M, Guo B, Song YF, Zhang Y.Graded ultratranslucent zirconia (5Y-PSZ) for strength and functionalities. J Dent Res.20180ct;97(11):1222-1228.doi:10.1177/0022034518771287.

6. Alraheam IA, Donovan TE, Rodgers B, Boushell L, Sulaiman TA. Effect of masticatory simulation on the translucency of different types of dental zirconia. JProsthet Dent.2019 Oct;122(4):404-409.doi:10.1016/j. prosdent.2019.02.002.

7. Nassary Zadeh P,Lümkemann N, Sener B, Eichberger M, Stawarczyk B. Flexural strength, fracture toughness, and translucency of cubic/tetragonal zirconia materials. J ProsthetDent.2018 Dec;120(6):948-954.doi:10.1016/j. prosdent.2017.12.021.

8. Vult von Steyern P,Carlson P,Nilner K. All-ceramic fixed partial dentures designed according to the dc-zirkon technique. A 2-year clinical study. J Ora Rehabil.2005 Mar;32(3):180-7.doi.org/10.1111/.1365-2842.2004.01437.x.

9. Sailer I,Pjetursson BE, Zwahlen M, Hämmerle CH. A systematic review of the survival and complication rates of all-ceramic and metal-ceramic reconstructions after an observation period of at least 3 years. Part ll: Fixed dental prostheses [published correction appears in Clin Oral Implants
Res:2008 Mar:19(3):326-8].Clin Oral Implants Res.2007:18 Suppl 3:86 96 doi:10.1111/1.1600-0501.2007.01468.x.

10. Tinschert J, Schulze KA, Natt G, Latzke P,Heussen N, Spiekermann H. Clinical behavior of zirconia-based fixed partial dentures made of DC-Zirkon:3-year results. Int J Prosthodont2008 May-Jun;21(3):217-22.

11. Rinke S, Fischer C. Range of indications for translucent zirconia modifications: clinical and technical aspects. Quintessence Int2013;44(8):557-66. doi:10.3290/j.qi.a29937.

12. Kim MJ, Kim YK, Kim KH, Kwon TY. Shear bond strengths of various luting cements to zirconia ceramic: surface chemical aspects. J Dent.2011Nov;39(11):795-803.doi: 10.1016/j.jdent.2011.08.012.

13. Blatz MB, Alvarez M, Sawyer K, Brindis M. How to bond zirconia:The APC concept. Compend Contin Educ Dent.2016 0ct;37(9):611-617;quiz 618.

14. Yang B,Barloi A, Kern M. Influence of air-abrasion on zirconia ceramic bonding using an adhesive composite resin. Dent Mater.2010Jan;26(1):44-50.doi: 10.1016/j.dental.2009.08.008.

15. Inokoshi M, Kameyama A, De Munck J, Minakuchi S, Van Meerbeek B. Durable bonding to mechanically and/or chemically pre-treated dental zirconia. J Dent.2013Feb;41(2):170-9.doi:10.1016/j.jdent.2012.10.017.

16. Wolfart M, Lehmann F, WolfartS, Kern M. Durability of the resin bond strength to zirconia ceramic after using different surface conditioning methods. Dent Mater.2007;23(1):45-50. doi:10.1016/j.dental.2005.11.040

17. Yang B, Scharnberg M, Wolfart S, Quaas AC, Ludwig K, Adelung R, Kern M. Influence of contamination on bonding to zirconia ceramic. JBiomed Mater Res B Appl Biomater.2007 May;81(2):283-90.doi.org/10.1002/jbm.b.30664.

18. Dal Piva AMO, Tribst.JPM, Bottino MA. Evaluation of shear bond strength and shear stress on zirconia reinforced lithium silicate and high translucency zirconia. J Oral Res 2018;7(1):30-36.doi.org/10.17126/joralres.2018.007.

19. Nishigawa G, Maruo Y, Irie M, Oka M, Yoshihara K, Minagi S. Ultrasonic cleaning of silica-coated zirconia influences bond strength between zirconia and resin luting material. Dent Mater J.2008 Nov;27(6):842-8.doi:10.4012/dmj.27.842.

20. Paranhos MP,Burnett LH Jr, Magne P.Effect of Nd:YAG laser and CO2 laser treatment on the resin bond strength to zirconia ceramic. Quintessence Int:2011 Jan;42(1):79-89.

21. Bottino MA, Valandro LF, ScottiR, Buso L. Effect of surface treatments on the resin bond to zirconium-based ceramic.Int J Prosthodont.2005JanFeb;18(1):60-5. doi.org/10.1016/j.prosdent.2005.05.011.

22. Shahin R, Kern M. Effect of air-abrasion on the retention of zirconia ceramic crowns luted with different cements before and after artificial aging.Dent Mater.2010Sep;26(9):922-8. doi:10.1016/j.dental.2010.06.006.

23. Dérand P,Dérand T.Bond strength of luting cements to zirconium oxide ceramics. Int J Prosthodont.2000 Mar-Apr;13(2):131-5.

24. Attia A. Influence of surface treatment and cyclic loading on the durability of repaired all-ceramic crowns. J Appl Oral Sci.2010Mar-Apr;18(2):194-200 doi:10.1590/s1678-77572010000200015.

25. Blatz MB, Sadan A, Martin J, Lang B. In vitro evaluation of shear bond strengths of resin to densely-sintered high-purity zirconium-oxide ceramic after long-term storage and thermal cycling. JProsthet Dent.2004Apr;91(4):356-62.doi:10.1016/.jprosdent.2004.02.001.

26. Dias de Souza GM, Thompson VP,Braga RR. Effect of metal primers on microtensile bond strength between zirconia and resin cements. JProsthet Dent.2011May;:105(5):296-303. doi:10.1016/S0022-3913(11)60055-3.

27. Manso AP, Silva NR, Bonfante EA, Pegoraro TA, Dias RA, Carvalho RM. Cements and adhesives for all-ceramic restorations. Dent Clin North Am.2011 Apr;55(2):311-32, ix.doi:10.1016/j.cden.2011.01.011. 
28. Mirmohammadi H, Aboushelib MN, SalamehZ, Feilzer AJ, Kleverlaan CJ. Innovations in bonding to zirconia based ceramics: Part III. Phosphate monomer resin cements. Dent Mater.2010 Aug;26(8):786-92.doi:10.1016/j. dental.2010.04.003.

29. Yang B, Lange-Jansen HC, Scharnberg M, Wolfart S, LudwigK, Adelung R, Kern M. Influence of saliva contamination on zirconia ceramic bonding. Dent Mater.2008 Apr;24(4):508-13.doi:10.1016/.jdental.2007.04.013.

30. Angkasith P,Burgess JO, Bottino MC, Lawson NC. Cleaning methods for zirconia following salivary contamination. J Prosthodont.2016Jul;25(5):375-9. doi:10.1111/jopr.12441.

31. Feitosa SA, Patel D, Borges AL, AlshehriEZ, Bottino MA, Özcan M, etal. Effect of cleansing methods on saliva-contaminated zirconia-An evaluation of resin bond durability. Oper Dent.2015 Mar-Apr;40(2):163-71.doi:10.2341/13-323-L.

32. Yoshida K. Influence of cleaning methods on resin bonding to salivacontaminated zirconia. J Esthet Restor Dent2018 May;30(3):259-264. doi:10.1111/jerd.12369.

33. Zhang S, Kocjan A, Lehmann F, Kosmač T, Kern M. Influence of contamination on resin bond strength to nano-structured alumina-coated zirconia ceramic Eur J Oral Sci.2010 Aug;118(4):396-403.doi:10.1111/j.1600-0722.2010.00752.x.

34. Tunc EP,Chebib N, Sen D, Zandparsa R. Effectiveness of different surface cleaning methods on the shear bond strength of resin cement to contaminated zirconia: an in vitro study. J Adhes Sci Technol.2016;30:554-565. doi.org/10.1080/01694243.2015.1111833.

35. Quaas AC, Yang B, Kern M. Panavia F2.0 bonding to contaminated zirconia ceramic after different cleaning procedures. Dent Mater.2007Apr;23(4):506-12. doi:10.1016/.jdental.2006.03.008.

36. Krifka S, Preis V, Rosentritt M. Effect of decontamination and cleaning on the shear bond strength of high translucency zirconia. Dent J (Basel).2017Nov14;5(4).pii:E32.doi:10.3390/dj5040032.

37. DelCarpio-Perochena AE, Bramante CM, Duarte MA, Cavenago BC, Villas-Boas $\mathrm{MH}$, Graeff MS, et al. Biofilm dissolution and cleaning ability of different irrigant solutions on intraorally infected dentin. JEndod. 2011Aug;37(8):1134-8.doi: 10.1016/j.joen.2011.04.013.

38. Aladağ A, Elter B, ÇömlekoğluE, Kanat B, Sonugelen M, Kesercioğlu A Özcan M. Effect of different cleaning regimens on the adhesion of resin to saliva-contaminated ceramics. J Prosthodont.2015 Feb;24(2):136-45.doi:10.1111/ jopr.12170.
39. Ishii R, Tsujimoto A, Takamizawa T, Tsubota K, Suzuki T, Shimamura Y,Miyazaki M. Dent Mater J. Influence of surface treatment of contaminated zirconia on surface free energy and resin cement bonding.2015;34(1):91-7.doi:10.4012/ dmj.2014-066.

40. Kim DH, Son JS, Jeong SH, Kim YK, Kim KH, Kwon TY. Efficacy of various cleaning solutions on saliva-contaminated zirconia for improved resin bonding. J Adv Prosthodont.2015 Apr;7(2):85-92.doi:10.4047/jap.2015.7.2.85.

41. Pereira Lde L,CamposF,Dal Piva AM, Gondim LD, Souza RO,Özcan M. Can application of universal primers alone be a substitute for airborne-particle abrasion to improve adhesion of resin cement to zirconia? J Adhes Dent.2015Apr;17(2):169-74.doi: 10.3290/j.jad.a33974.

42. Hussain AM, Al-Azzawi AJ. Shear bond strength between lithium disilicate ceramic and different luting cements. J Prosthet Dent 2015;3:212-217.

43. Gomes AL, Ramos JC, Santos-del Riego S, Montero J, Albaladejo A. Thermocycling effect on microshear bond strength to zirconia ceramic using Er:YAG and tribochemical silica coating as surface conditioning. Lasers Med Sci.2015Feb;30(2):787-95.doi:101007/s10103-013-1433-z.

44. Harnirattisai C, Roengrungreang P,RangsisiripaiboonU, Senawongse P.Shear and micro-shear bond strengths of four self-etching adhesives measured immediately and 24 $\mathrm{h}$ after application. Dent Mater J.2012;31(5):779-787. doi:10.4012/dmj.2012-013

45. Andrade AM, Moura SK, Reis A, Loguercio AD, GarciaEJ, Grande RH. Evaluating resin-enamel bonds by microshear and microtensile bond strength tests: effects of composite resin. J Appl Oral Sci.2010;18(6):591-598.doi:10.1590/ s1678-77572010000600010.

46. Qeblawi DM, Campillo-Funollet M, Muñoz CA. In vitro shear bond strength of two self-adhesive resin cements to zirconia. JProsthet Dent.2015Feb;113(2):122-7.doi:10.1016/.jprosdent.2014.08.006.

47. Ehlers V,Kampf G, Stender E, Willershausen B,Ernst CP.Effect of thermocycling with or without 1 year of water storage on retentive strengths of luting cements for zirconia crowns. J Prosthet Dent.2015Jun;113(6):609-15. doi:10.1016/j.prosdent.2014.12.001.

\section{Dr. Mazen Ahmed Attia}

(Corresponding address)

Department of Fixed Prosthodontics

Faculty of Dentistry, Beni-Suef University, Beni-Suef, Egypt

Salah Salem Str., Beni- Suef, Egypt

E-mail: mazen.ahmed@dent.bsu.edu.eg

Date submitted: 2020 Apr 21

Accept submission: 2020 Jun 01 